\title{
The Effect of Fraud Disclosure, Internal Control, Information Technology on Corporate Governance and Corporate Performance as Moderating Variable
}

\author{
Zuhal Maftuh Ahnan \\ Faculty of Economics and Business Universitas Mercu Buana \\ Jl. Meruya Selatan No.31, RT.4/RW.1, Meruya Sel., Kec. Kembangan, Kota Jakarta Barat, Daerah Khusus \\ Ibukota Jakarta 11610
}

\begin{abstract}
This research is a quantitative causality study that analyzes the effect of fraud disclosure, internal control, information technology on corporate performance and corporate governance as moderating variables. The results of this study are expected to contribute to the existing literature by overcoming some of the limitations articulated from previous studies. First, it offers new empirical insights on company risk and disclosure of fraud by management by basing research in behavioral theories that emerge from the board of directors and corporate governance, where corporate decision making is not only assumed to be underlined by formal approaches and CG mechanisms, but also CG arrangements informal, limited rationality, political bargaining, routine and satisfying behavior. The fixed-effect regression model is used to study the relationship of fraud disclosure, internal control and information technology of financial performance while the random-effect regression model is used from nonfinancial performance. Panel data of 192 sample observations from public companies in the banking sector which are listed on the Indonesia Stock Exchange and are included in the Top 50 ASEAN Scorecard. The findings show the disclosure of fraud, internal control and information technology have a positive effect on company performance, both financial and non-financial performance and corporate governances strengthen the financial performance but weaken the non-financial performance
\end{abstract}

Keywords: Disclosure of Fraud, Internal Control, Information Technology, Corporate Performance, Corporate Governance

DOI: $10.7176 / \mathrm{EJBM} / 12-33-09$

Publication date: November $30^{\text {th }} 2020$

\section{Introduction}

The progress of a country's economy can be measured in various ways one of which is capital market activity in the country. Indonesia's large and growing economy is a land for foreign investors to make a profit, especially through the capital market. Ideally, company performance as the biggest production factor depicts economic performance.

The company's performance is the fruit of the results of several objects that become decisions of individuals continuously by the management concerned. An assessment of a company's financial performance can be done by analyzing its financial performance The financial performance report is used as a source of information for shareholders and the general public regarding the business activities of the company (Zhao et, al 2018). Both index performance and economic performance, we certainly hope that the Indonesian index performance is able to represent overall economic performance.

The structure of CG influences a number of aspects of its business model, including setting company goals and how those objectives must be achieved, monitoring and assessing risk and optimizing performance. Minna (2011) found that analysts tend to provide favorable recommendations for companies with better CG mechanisms. It is also expected that $\mathrm{CG}$ increases corporate oversight of earnings and reduces management manipulation and increases the reliability of financial statements (Leuz et al., 2003; La Porta et al., 2002). Of course, a strong CG structure will provide a powerful monitoring tool for managerial decision making and limit activities that have an impact on company performance both in the use of company resources and with the implementation of information technology developed or adopted by the company.

Research contributes to the existing literature by overcoming some of the limitations articulated from previous studies. First, it offers new empirical insights on company risk and disclosure of fraud by management by basing our research on behavioral theories that emerge from the board of directors and corporate governance, where corporate decision making is not only assumed to be underlined by formal approaches and CG mechanisms, but also CG arrangements informal, limited rationality, political bargaining, routine and satisfying behavior (Van Ees et al., 2009; Huse et al., 2011). 


\section{Literature Review and Hypotheses Development}

\subsection{Agency Theory}

Basically, an agent will not give up before his personal interests are fulfilled (Kasum et al. 2011). To explain this, agency theory is well suited for use. Agency theory connects shareholders (principals) and management (agents) who have different interests (Jensen and Meckling 1976). Agency theory tries to explain that management has greater information related to company operations than shareholders. This imbalance of information causes conflict (Glover et al. 2006).

\subsection{Fraud Disclosure}

Fraud occurs when a misstatement is made in a situation that knows that it is a fake and is carried out with the intent to commit fraud. Arens and Loebbecke (1997). An act or process of fraud or concealment of deliberate neglect or deviation from the truth such as breaking the law and acting unfairly (Sorunke, et al., 2016). Acts or paths of fraud, deliberate concealment, negligence, or distortion of the truth, to (1) obtain unauthorized or unjust benefits, (2) encourage other parties to take part with valuables or surrender legal rights, or (3) give rise to injury in several ways. Deliberate fraud is a criminal offense that requires severe punishment, and prosecution and punishment (such as murder) are not bound by statute of limitations. But the inability or negligence in managing a business or even the wasteful disposal of company assets (by speculating on the stock market, for example) is usually not fraud.

\subsection{Internal Control}

Products that have been produced by COSO include Internal Control - Integrated Framework (1992) and Enterprise Risk Management - Integrated Framework (1994). Indonesia adopted Internal Control - Integrated Framework (1992) in Government Regulation No. 60/2008 concerning Government Internal Control Systems. In its development, COSO has released the latest IC framework, Internal Control - Integrated Framework (2013) to replace the old IC framework.

\subsection{Information Technology}

The value of IT business seems to have explained this relationship through what is called the IT capability perspective of supported organizations (Rai et al., 2006). From this perspective, IT has an indirect, not direct, impact on company performance through high-level process capabilities. Thus, IT plays a key role in shaping the capabilities of other organizations that create performance advantages for companies, such as developing dynamic new product development (NPD) capabilities and NPD functional competencies (Pavlou and El Sawy, 2006) and supply chain integration capabilities (Rai et al, 2006).

\subsection{Corporate Governances}

Cheng et al. (2014) explains that corporate governance is governance within a company that can direct and control the company. In a company, the function of directors is a corporate governance mechanism. In the concept of corporate governance, there are two important things that must be known. These two important things are the right of shareholders to obtain information and the obligation of company management to disclose accurately, timely, and transparent to all information related to company performance, ownership, and stakeholders (Kaihatu 2006).

\subsection{Hypotheses Development}

2.6.1 Disclosure of Fraud, Corporate Governance and Corporate Performance.

Agency theory connects shareholders (principals) and management (agents) who have different interests (Jensen and Meckling 1976). Our hypothesis is that corporate performance is an important driver of corporate fraud in accordance with Cressey's fraud triangle (Cressey, 1950, 1953). This research contributes to the literature on corporate fraud theory, which seeks to explain what motivates companies to commit fraud (Finnerty et al., 2016, Trompeter et al., 2013).

H1. Disclosure of fraud has a positive effect on corporate performance.

Saidi (2011) shows that corporate governance reforms in the developed capital market are often driven by investors, whereas in the GCC, the burden of improving corporate governance lies with regulators because of the ownership structure of the company (especially family or country) and the availability of liquidity and financing to form regional banks .

H2. CG strengthens the disclosure relationship on corporate performance fraud.

\subsubsection{Internal Control, Corporate Governance and Corporate Performance}

As a formal institutional arrangement, internal internal conductive to improve the quality of business decisions (D'Mello, Gao, \& Jia, 2017), increase the efficiency of resource allocation (Cheng et al., 2013), improve corporate governance and reduce corporate risk taking (Bargeron, Lehn, \& Zutter, 2010). As required by the Company's Internal Control Standards, internal control must focus on important business issues and high-risk areas under full 
scale control, and then determine the company's risk response strategy. It also emphasizes the importance of recognizing internal and external risks in daily operations.

H3. Internal control has a positive effect on corporate performance.

The presence of the board of directors at the company is very important to monitor management decisions and ensure that they disclose credible voluntary information rather than self-serving according to Healy and Palepu (2001), helping provide some reference information for stakeholders and regulators to help improve financial statements. Therefore, there is a need to assess (measure) the disclosure of internal control information in these companies, so that they can be improved.

H4. Corporate governance strengthens internal control relationships with corporate performance. 2.6.3 Information Technology, Corporate Governance and Corporate Performance

The literature review starts with the most basic argument (i.e. IT capabilities affect company performance). Furthermore, based on the influence of time, the company's current and future performance must be distinguished. Thus, the lag effect and the ongoing effect of information technology can be explained. In short, IT capabilities simultaneously show good performance, future company performance, and corporate value (Ong and Chen, 2013)

H5. Information technology has a positive effect on company performance.

The role of corporate governance and IT in preventing and detecting fraud adds little research to this topic, especially in Asean and developing countries. There are significant consequences for companies due to lack of fraud prevention and detection practices. Therefore, the results of this study can provide more information to senior management and the company's board of directors, so that they are more aware of the importance of their supervisory function, ethical behavior, their own behavior and tone and effective corporate governance to avoid future companies. . failure (Halbouni and Garbou, 2016).

H6. Corporate governance strengthens the relationship between information technology and company performance.

\section{Research methodology}

3.1 Population dan Sample

Population uses secondary financial statement data from public banking companies listed on the Indonesia Stock Exchange. This study uses non-random sampling technique, namely purposive sampling. The total banking 48 companies, the observation period from 2015-2018 was 4 years so that 192 observations obtained.

\subsection{Research Model}

The method used for hypothesis testing in this study is the panel data method (pooled regression), using data analysis tools in the form of Eviews software. The quantitative method that will be used in this study is a dynamic causal econometric analysis by applying the least squares method to the fixed effect model or the random effect model. After that, a series of statistical tests are performed using the Chow Test and the Hausmann Test to get the optimal model to explain the results of this study.

Hypothesis Equations:

(i) $\mathrm{FP}=\alpha \mathbf{0}+\alpha \mathbf{1 ~ F D}+\alpha 2 \mathrm{IC}+\alpha 3 \mathrm{TI}+\mathrm{e}$

(ii) $\mathrm{FP}=\alpha \mathbf{0}+\alpha 1 \mathrm{FD}+\alpha 2 \mathrm{FD} * \mathrm{CG}+\alpha 3 \mathrm{IC}+\alpha 4 \mathrm{IC} * \mathrm{CG}+\alpha 5 \mathrm{TI}+\alpha 6 \mathrm{TI} * \mathrm{CG}+\varepsilon$

$\alpha 0=$ Constant

$\alpha 1-\alpha 6=$ Cohesive regression

$\mathrm{FP}=$ Corporate Performance

FD $\quad$ Fraud Disclosure

IC = Internal Control

$\mathrm{TI} \quad=$ Information Technology

$\mathrm{CG}=$ Corporate Governance

$\varepsilon \quad=$ Error

\section{Result and Discussion}

4.1 Descriptive Statistics

Table 1. descriptive statistics for all variables used in this study. The natural logarithm value of the tenure of directors of directors (TEN) is 77.8 indicating that BOD generally has a relatively high BOD experience. Around 19.3 BOD also served as an audit committee or corporate governance (AGC) and compensation or nomination committee (CNC). In terms of BOD strength, around 43.2 percent of CEOs simultaneously served as chairman of the board of directors (DUAL); Their share ownership is relatively high (SHARE average of 43.2 percent). In addition, most BOD adhered to attending board meetings (LOWATT) and quite high had many outside director positions (OUTB) (average LOWATT and OUTB were 0.010 and 0.438 , respectively). 
Table 1. descriptive statistics

\begin{tabular}{|lrrrrrrr}
\hline \multicolumn{1}{|c}{ Variable } & No & Mean & Med & Max. & Min. & $\underline{\text { S.D }}$ \\
\hline $\begin{array}{l}\text { Dependent Variable } \\
\text { Financial Performance }\end{array}$ & & & & & & \\
$\quad$ NIM & 192 & 4,720 & 4,700 & 12,000 & $-11,570$ & 2,331 \\
$\quad$ ROA & 192 & 1,044 & 1,200 & 10,770 & $-11,150$ & 2,282 \\
$\quad$ ROE & 192 & 4,978 & 7,620 & 31,220 & $-94,010$ & 17,894 \\
Non-Financial Performance & & & & & & \\
$\quad$ CUST & 192 & 1,708 & 2,000 & 3,000 & 1,000 & 0,586 \\
$\quad$ FIN & 192 & 1,943 & 2,000 & 3,000 & 1,000 & 0,774 \\
$\quad$ IB & 192 & 1,495 & 1,000 & 3,000 & 0,000 & 0,579 \\
IL & 192 & 1,375 & 1,500 & 3,000 & 0,000 & 0,952 \\
Independent Variable & & & & & & \\
Pengungkapan Kecurangan & 192 & 3,661 & 4,000 & 5,000 & 0,000 & 1,401 \\
Internal Control & 192 & 0,364 & 0,000 & 1,000 & 0,000 & 0,531 \\
Teknologi Informasi & 192 & 0,234 & 0,000 & 1,000 & 0,000 & 0,233 \\
Moderate Variable & & & & & & \\
Corporate Governances & & & & & & \\
$\quad$ AGC & 192 & 0,193 & 0,000 & 1,000 & 0,000 & 0,395 \\
$\quad$ DUAL & 192 & 0,432 & 0,000 & 1,000 & 0,000 & 0,497 \\
$\quad$ LNTEN & 192 & 0,778 & 1,099 & 1,609 & 0,000 & 0,605 \\
$\quad$ LOWATT & 192 & 0,010 & 0,000 & 1,000 & 0,000 & 0,102 \\
OUTB & 192 & 0,438 & 0,000 & 1,000 & 0,000 & 0,497 \\
SHARE & 192 & 0,432 & 0,000 & 1,000 & 0,000 & 0,497 \\
\hline
\end{tabular}

\subsection{Result \& Discussion}

Table 2: The Effect of fraud disclosure, internal control, information technology and corporate governances on financial performance.

\begin{tabular}{|c|c|c|c|c|c|c|c|c|c|c|c|c|}
\hline \multirow{4}{*}{ Yariabel } & \multicolumn{12}{|c|}{ Financial Performance } \\
\hline & \multicolumn{12}{|c|}{$\mathrm{FP}=\alpha 0+\alpha 1 \mathrm{FD}+\alpha 2 \mathrm{FD}^{*} \mathrm{CG}+\alpha 3 \mathrm{IC}+\alpha 4 \mathrm{IC}^{*} \mathrm{CG}+\alpha 5 \mathrm{TI}+\alpha 6 \mathrm{TI}{ }^{*} \mathrm{CG}+\varepsilon$} \\
\hline & \multicolumn{4}{|c|}{ ROA } & \multicolumn{4}{|c|}{ ROE } & \multicolumn{4}{|c|}{ NIM } \\
\hline & Coeff. & t-Stat. & Pro & & Coeff. & t-Stat. & Pro & & Coeff. & t-Stat. & Prol & \\
\hline FD & 6,68 & 4,40 & 0,00 & *** & 7,19 & 0,57 & 0,57 & & $(0,87)$ & $(0,81)$ & 0,42 & \\
\hline IC & $(5,53)$ & $(2,79)$ & 0,01 & *** & $(39,65)$ & $(2,40)$ & 0,02 & ** & $(0,55)$ & $(0,64)$ & 0,52 & \\
\hline TI & 0,04 & 0,25 & 0,80 & & 2,83 & 2,00 & 0,05 & ** & 0,45 & 3,21 & 0,00 & *** \\
\hline FD*CG & 1,97 & 4,36 & 0,00 & $* * *$ & 12,80 & 3,40 & 0,00 & $* * *$ & $(0,00)$ & $(0,01)$ & 0,99 & \\
\hline $\mathrm{IC} * \mathrm{CG}$ & $(1,33)$ & $(3,86)$ & 0,00 & *** & $(5,99)$ & $(2,08)$ & 0,04 & ** & $(0,19)$ & $(0,72)$ & 0,47 & \\
\hline $\mathrm{TI}^{*} \mathrm{CG}$ & 0,46 & 1,66 & 0,10 & * & 3,41 & 1,48 & 0,14 & & 0,05 & 0,25 & 0,81 & \\
\hline $\mathbf{N}$ & 192 & & & & & & & & & & & \\
\hline Adjusted R-squared & 0,5960 & & & & 0,5430 & & & & 0,1272 & & & \\
\hline Prob(F-statistic) & 0,0000 & & & & 0,0000 & & & & 0,0004 & & & \\
\hline $\mathbf{C}$ & 5.279 & & & & 20.805 & & & & 0.859 & & & \\
\hline (Prob.) & 0.01 & & & & 0.21 & & & & 0.44 & & & \\
\hline
\end{tabular}

Note: ${ }^{* * *} \mathrm{p}<0.01 ;{ }^{* *} \mathrm{p}<0.05 ;{ }^{*} \mathrm{p}<0.1$

Agency theory connects shareholders (principals) and management (agents) who have different interests (Jensen and Meckling 1976), stakeholder theory suggests that if we adopt as an analysis unit the relationship between businesses and groups and individuals who can influence or be influenced by it then we have a better chance to deal effectively. Referring to table 2, the panel data regression results of the disclosure relationship between fraud (FD), internal control (IC) and information technology (IT) on the company's financial performance (FP): ROA, ROE and NIM show all have a positive relationship but only a significant ROA. These results indicate conformity with research conducted by Finnerty et al., (2016), Trompeter et al., (2013), Hogan et.al. (2008), Halbouni and Garbou (2016), Ong and Chen (2013) with the influence of 59.6\% ROA, 54.3\% ROE and $12.72 \%$ NIM.

In table 2, the panel data regression results of the disclosure of fraud (FD), internal control (IC) and information technology (IT) relationships to the company's financial performance (FP) moderated by corporate governances (CG) show that corporate governances (CG) strengthen the relationship disclosure of fraud (FD), internal control (IC) and information technology (IT) on the company's financial performance (FP), especially ROA which looks significant. This is in accordance with research by Saidi (2011), Bargeron, Lehn, \& Zutter 
(2010), Caroline Simorangkir, R. T. M., Solihati, G. P.,. M., \& Subiyanto, B., (2019).

So it was concluded that hypothesis 1 to hypothesis 6 was accepted to have an effect on the company's financial performance. The importance of disclosure of fraud (FD), internal control (IC) and information technology (IT) on the company's financial performance (FP) through ROA indicators is still considered reliable to ensure stakeholder satisfaction. And the influence of corporate governances is still visible.

Table 3: The Effect of fraud disclosure, internal control, information technology and corporate governances on non- financial performance.

\begin{tabular}{|c|c|c|c|c|c|c|c|c|c|c|c|c|c|c|c|c|}
\hline \multirow{4}{*}{ Variabel } & \multicolumn{16}{|c|}{ Non-Financial Performance } \\
\hline & \multicolumn{16}{|c|}{$\mathrm{NFP}=\alpha 0+\alpha 1 \mathrm{FD}+\alpha 2 \mathrm{FD}^{*} \mathrm{CG}+\alpha 3 \mathrm{IC}+\alpha 4 \mathrm{IC}^{*} \mathrm{CG}+\alpha 5 \mathrm{TI}+\alpha 6 \mathrm{TI}^{*} \mathrm{CG}+\varepsilon$} \\
\hline & \multicolumn{4}{|c|}{ FIN } & \multicolumn{4}{|c|}{ COST } & \multicolumn{4}{|c|}{ IB } & \multicolumn{4}{|c|}{ IL } \\
\hline & Coeff. & t-Stat. & Pro & & Coeff. & t-Stat. & Prob & & Coeff. & t-Stat. & Prob & & Coeff. & t-Stat. & Prob & \\
\hline FD & 0,74 & 2,71 & 0,01 & *** & 0,15 & 0,56 & 0,57 & & $(0,49)$ & $(1,38)$ & 0,17 & & 0,09 & 0,22 & 0,83 & \\
\hline IC & 0,70 & 2,93 & 0,00 & $* * *$ & 0,55 & 2,51 & 0,01 & $* * *$ & $(0,16)$ & $(0,34)$ & 0,73 & & 0,57 & 1,74 & 0,08 & * \\
\hline TI & 0,08 & 0,13 & 0,90 & & 0,60 & 0,92 & 0,36 & & 1,40 & 1,74 & 0,08 & * & $(1,56)$ & $(1,61)$ & 0,11 & \\
\hline FD*CG & $(0,05)$ & $(0,56)$ & 0,58 & & $(0,01)$ & $(0,15)$ & 0,88 & & 0,11 & 1,02 & 0,31 & & $(0,13)$ & $(1,10)$ & 0,27 & \\
\hline IC*CG & $(0,18)$ & $(2,81)$ & 0,01 & $* * *$ & $(0,04)$ & $(0,62)$ & 0,54 & & $(0,00)$ & $(0,03)$ & 0,97 & & 0,03 & 0,25 & 0,80 & \\
\hline $\mathrm{TI}^{*} \mathrm{CG}$ & $(0,15)$ & $(2,92)$ & 0,00 & $* * *$ & $(0,10)$ & $(1,93)$ & 0,06 & * & $(0,12)$ & $(1,91)$ & 0,06 & * & $(0,13)$ & $(1,67)$ & 0,10 & * \\
\hline $\mathbf{N}$ & 192 & & & & & & & & & & & & & & & \\
\hline Adjusted R-squared & 0,0842 & & & & 0,0807 & & & & 0,6537 & & & & 0,1335 & & & \\
\hline Prob(F-statistic) & 0,0076 & & & & 0,0095 & & & & 0,0000 & & & & 0,0002 & & & \\
\hline $\mathrm{C}$ & 1.195 & & & & 0.979 & & & & 1.593 & & & & $(0.379)$ & & & \\
\hline (Prob.) & 0.00 & & & & 0.00 & & & & 0.00 & & & & 0.37 & & & \\
\hline
\end{tabular}

The panel data regression results of the disclosure relationship cheating (FD), internal control (IC) and information technology (IT) on the company's non-financial performance (FP): FIN, COST, IB and IL in table 3 show all have a positive relationship and only IL that does not significant with the influence of $8.42 \%$ FIN, $8.07 \%$ COST, $65.37 \%$ IB and $13.35 \%$ IL.

In table 3 , the panel data regression results of the disclosure of fraud (FD), internal control (IC) and information technology (IT) relationships on corporate financial performance (FP) moderated by corporate governances $(\mathrm{CG})$ indicate that corporate governances $(\mathrm{CG})$ weaken the relationship disclosure of fraud (FD), internal control (IC) and information technology (IT) on the company's non-financial performance (FP). So it was concluded that hypotheses 2, 4 and 5 were rejected. And corporate governances have no visible effect on nonfinancial performance.

\section{Conclusions, Limitaitons and Suggestions}

5.1 Conclusions

The structure of CG influences a number of aspects of its business model, including setting company goals and how those objectives must be achieved, monitoring and assessing risk and optimizing performance. Of course, a strong CG structure will provide a powerful monitoring tool for managerial decision making and limit activities that have an impact on company performance both in the use of company resources and with the implementation of information technology developed or adopted by the company. So it can be concluded, disclosure of fraud, internal control and information technology has a positive effect on company performance, both financial and nonfinancial performance and corporate governances strengthen the financial performance but weaken the nonfinancial performance.

\subsection{Limitations and Suggestions}

In this study, the sample data should comply with the presentation standards in the annual report in accordance with those regulated in Financial Services Authority Regulation No. 34 / POJK.04 / 2014. Many sample data that make revised financial statement data so that the data obtained is not consistent. For further research can include a larger sample of companies. For financial performance, you can see Tobin-Q measurement, besides that a comparison can be made for companies that have not yet entered the Top 50 Asean Scorecard.

\section{References}

Amran, N. A., Yusof, M. 'Atef M., Ishak, R., \& Aripin, N. (2014). Do Characteristics of CEO and Chairman Influence Government- Linked Companies performance? Procedia-Social and Behavioral Sciences. https://doi.org/10.1016/j.sbspro.2013.12.546

Bargeron, L. L., Lehn, K. M., \& Zutter, C. J. (2010). Sarbanes-Oxley and corporate risk- aking. Journal of Accounting and Economics, 49(1), 34-52.

Ben Kwame Agyei-Mensah, (2016) "Internal control information disclosure and corporate governance: evidence from an emerging market", Corporate Governance: The International Journal of Business in Society, Vol. 16 Issue: 1, pp.79-95,

Caroline Simorangkir, R. T. M., Solihati, G. P., . M., \& Subiyanto, B. (2019). Implication of Internal Audit Quality, 
Job Satisfaction, Asimetric Information and Good Governance on Accounting Fraudulent Tendency. Saudi Journal of Business and Management Studies, 04(12), 878-887. https://doi.org/10.36348/sjbms.2019.v04i12.003

Cheng, B., I. Ioannou, and G. Serafeim. 2014. Corporate social responsibility and access to finance. Strategic Management Journal 35(1): 1-23.

Cheng, M., Dhaliwal, D., \& Zhang, Y. (2013). Does investment efficiency improve after the disclosure of material weaknesses in internal control over financial reporting? Journal of Accounting and Economics, 56(1), 1-18.

Connelly, Brian and Certo, Trevis and Ireland, R and R. Reutzel, Christopher, 2011, Signaling Theory: A Review and Assessment, Journal of Management - J MANAGE, Vol.3, pp. 39-67

Cressey, D.R. (1950), "The criminal violation of financial trust", American Sociological Review, Vol. 15 No. 6 , pp. 738-743.

Cressey, D.R. (1953), Other People's Money: The Social Psychology of Embezzlement, Free Press, New York, NY.

D'Mello, R., Gao, X., \& Jia, Y. (2017). Internal control and internal capital allocation: Evidence from internal capital markets of multi-segment firms. Review of Accounting Studies, 22(1), 251-287

Finnerty, J. D., Hegde, S., \& Malone, C. B. (2016). Fraud and firm performance: keeping the good times (apparently) rolling. Managerial Finance. https://doi.org/10.1108/MF-01-2015- 0009

Fraud. BusinessDictionary.com. Retrieved July 09, 2018, from BusinessDictionary.com website: http://www.businessdictionary.com/definition/fraud.html

Freeman, R.E. (1984). Strategic management: A stakeholder approach. Boston: Pitman Publishing Inc.

Glover, S. M., W. F. Messier, and D. F. Prawitt. 2006. Auditing \& Assurance Services: A Systematic Approach. New York: McGraw-Hill Education.

Hailin Zhao, Haimeng Teng, Qiang Wu,2018, The effect of corporate culture on firm performance: Evidence from China. China Journal of Accounting Research,Volume 11, Issue 1,Pages 1-19

Healy, P.M. and Palepu, K.G. (2001), "Information asymmetry, corporate disclosure, and the capital markets: a review of the empirical disclosure literature", Journal of Accounting and Economics, Vol. 31 No. 3, pp. 405440.

Hogan, C.E., Rezaee, Z., Riley, R.A. and Velury, U.K. (2008), "Financial statement fraud: insight from the academic literature", Auditing: A Journal of Practice and Theory, Vol. 27 No. 2, pp. 231-252.

Huse, M., Hoskisson, R., Zattoni, A. and Vigano, R. (2011), "New perspectives on board research: changing the research agenda", Journal of Management and Governance, Vol. 15 No. 1, pp. 5-28.

Husin, N. M., Hooper, K., \& Olesen, K. (2012). Analysis of intellectual capital disclosure - an illustrative example. Journal of Intellectual Capital.

Jensen, M.C. and Meckling, W.H. (1976), "Theory of the firm: managerial behaviour, agency costs and ownership structure", Journal of Financial Economics, Vol. 3 No. 4, pp. 305- 360.

Kaihatu, Thomas S., (2006). "Good Corporate Governance dan Penerapannya di Indonesia", Jurnal Manajemen dan Kewirausahaan, Volume 8 No. 1 hal 1-9.

Kaplan, R. S. (2010). Conceptual Foundations of the Balanced Scorecard. Harvard Business School. https://doi.org/10.1016/S1751-3243(07)03003-9

Kasum, A. S., E. Muthar, F. Oyebola, and A. Abdulraheem. 2011. Agency Problem in Corporate Governance in the Nigerian Banking Industry: A Review. Working Paper, University of Ilorin, Nigeria.

Kesner, I.F. (1988), "Directors' characteristics and committee membership: An investigation of type, occupation, tenure, and gender", The Academy of Management Journal, Vol. 31 No. 1, pp. 66-84.

La Porta, R., Lopez-de-Silanes, F., Schleifer, A., 2002. Government ownership of banks. Journal of Finance 57 (1), 265-301.

Leng, J. and Ding, Y. (2011), "Internal control disclosure and corporate governance: empirical research from Chinese listed companies”, Technology and Investment, Vol. 2 No. 1, pp. 286-294.

Leuz, C., Oberholzer-Gee, F., 2003. Corporate transparency and political connections. Working paper, University of Pennsylvania, Wharton.

Minna $\mathrm{Yu}$, (2011) "Analyst recommendations and corporate governance in emerging markets", International Journal of Accounting \& Information Management, Vol. 19 Issue: 1, pp.34-52

Naser, K., Al-Hussaini, A., Al-Kwari, D. and Nuseibeh, R. (2006), "Determinants of corporate social disclosure in developing countries: the case of Qatar", Advances in International Accounting, Vol. 19 No. 1, pp.

Nourayi, M. M., \& Mintz, S. M. (2008). Tenure, firm's performance, and CEO's compensation. Managerial Finance. https://doi.org/10.1108/03074350810874055

Pavlou, P.A. and El Sawy, O.A. (2006), "From IT leveraging competence to competitive advantage in turbulent environments: the case of new product development", Information Systems Research, Vol. 17 No. 3, pp. 198227.

Raar, J. (2002). Environmental initiatives: Towards triple-bottom line reporting. Corporate Communications: An 
International Journal.

Rai, A., Patnayakuni, R. and Seth, N. (2006), "Firm performance impacts of digitally enabled supply chain integration capabilities", MIS Quarterly, Vol. 30 No. 2, pp. 225-46.

Saidi, N. (2011), "Corporate governance in the GCC: what has been done and what remains", Qatar Business Review, pp. 11-13.

Saputra, A. G. (2014). CRMS knowledge. Retrieved from CRMS Indonesia: http:/crmsindonesia.org/knowledge/crms-articles/tuntutan- kompetensi-manajemen-risiko- bagi-anggotakomite-audit-di-tingkat-gl. diakses pada 2 Februari 2017

Shocker, A.D. and Sethi, S.P. (1974), “An approach to incorporating action preferences in developing corporate action strategies”, in Sethi, S.P. (Ed.), The Unstable Ground: Corporate in a Dynamic Society, Melville, CA.

Trompeter, G.M., Carpenter, T.D., Desai, N., Jones, K.L. and Riley, R.A. Jr (2013), “A synthesis of fraud-related research", Auditing: A Journal of Practice \& Theory, Vol. 32 No. 1, pp. 287-321.

Van Ees, H., Gabrielsson, J. and Huse, M. (2009), "Toward a behavioral theory of boards and corporate governance", Corporate Governance: An International Review, Vol. 17 No. 3, pp. 307-319.

Walsh, J. P., (2005) Taking stock of stakeholder management. Academy of Management Review, 30(2), 426-438.

Wang, F., Xu, L., Zhang, J., \& Shu, W. (2018). Political connections, internal control and firm value: Evidence from China's anti-corruption campaign. Journal of Business Research. https://doi.org/10.1016/j.jbusres.2018.01.045

Wernerfelt, B. (1984), “A resource-based view of the firm”, Strategic Management Journal, Vol. 5 No. 2, pp. 17180.

Zhou, H., Chen, H., \& Cheng, Z. (2018). Internal Control, Corporate Life Cycle, and Firm Performance. In International Finance Review (pp. 189-209). 